\title{
The Relationship and Effect of Social Media on Student's Academic Performance: - University of Halabja as an Example
}

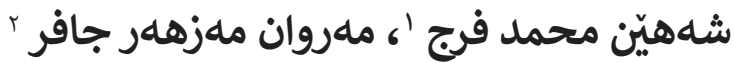

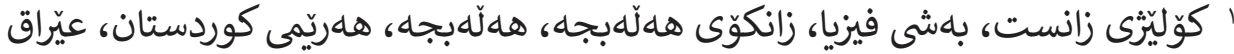

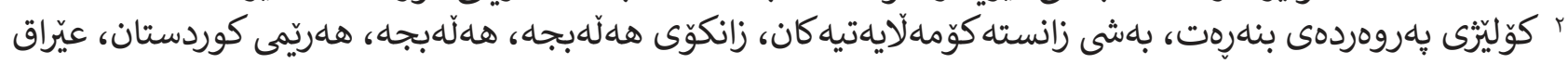

Corresponding author's e-mail: shahen.faraj@uoh.edu.iq

\begin{abstract}
Today the internet captures our daily life. Students rely on it, specifically Social Media, for different purposes. The main purpose of this study is to show the effect of social media on students' academic performance in both positive and negative aspects. By using Circular Systematic Sampling, a questionnaire form was constructed to collect information from 320 students from the University of Halabja-Kurdistan Region-Iraq. The data were analyzed by using Pearson Chi-Square test in SPSS V22 program to show the influence of social media on students' academic performance. It is concluded that students use social media most of the time on a different account like (Facebook, Messenger, Instagram...) for different purposes and that affects them positively and negatively. The research recommendation is that students must use social media for educational purpose. Otherwise, it affects their life negatively, especially their academic life.
\end{abstract}

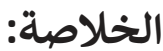

في يومنا الحاضر أصبح الانترنت من ضروريات حياتنا اليومية، ويعتمد عليها الطلاب وخاصة المواقع التواصل الاجتماعي ولأغراض مختلفة. الغرض الرئيسي من هذه الدراسة هو توضيح تأثير وسائل التواصل الاجتماعي على الأداء الأكاديمي للطلاب مع اظهار اثارها الإيجابيه والسلبيه. من خلال اخذ العينات المنظم الدائريه، تم إنشاء استمارة استبيان لجمع المعلومات من • بس طالبًا من جامعة حلبجةــ اقليم كردستانالعراق. تم استخدام اختبار Pearson Chi-Square من برنامج SPSS نسخة بr لإظهار تأثير وسائل التواصل الاجتماعي على الأداء الأكاديمي للطلاب. تم استنتاج ان الطلاب يستخدمون مواقع التواصل الاجتماعي اغلب الاوقات وعلى حسابات مختلفة مثل (فيسبوك، ماسنجر، انستغرام...) ولأغراض متعددة وهذا اثر عليهم ايجابيا وسلبيا. وفي توصية يجب يستخدم الطلاب مواقع التواصل الاجتماعي لأغراض تربويه وتعليميه، وإلاكان تأثير سلبيا عليهم خاصة على حياتهم الأكاديميه.

\begin{tabular}{|c|c|}
\hline \multicolumn{2}{|c|}{ 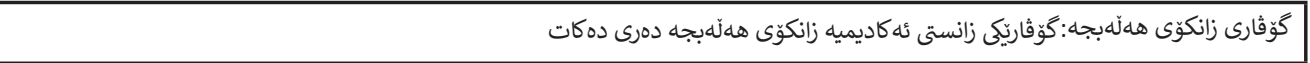 } \\
\hline 0 & بهرى \\
\hline 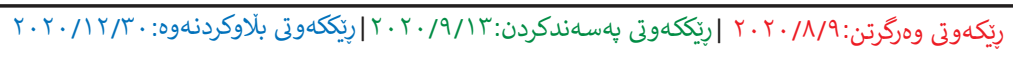 & 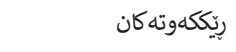 \\
\hline shahen.faraj@uoh.edu.iq & ئيمهيلى تويَّرَّر \\
\hline 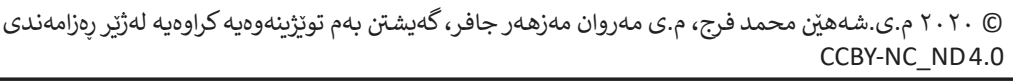 & 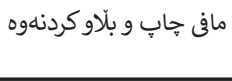 \\
\hline
\end{tabular}




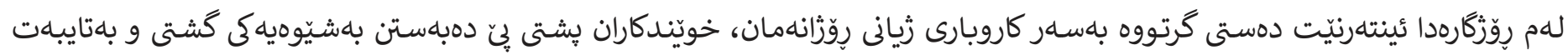

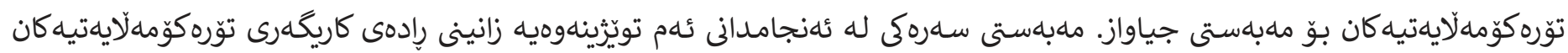

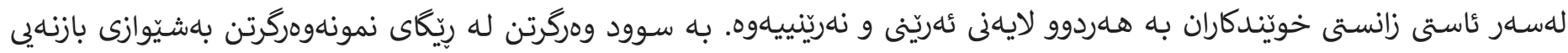

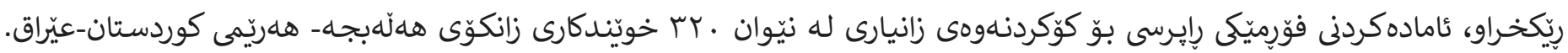

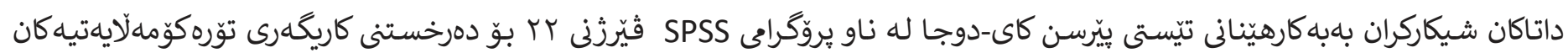
للهسه ئاستى زانستى خويّندكاران. له كوّتاييدا ئهم تويّرينهوهيه دهريدهخات كه زوّريهى كاتهكان خويّندكاران توَّرى كوّمهلاّيهتى جياواز وهك

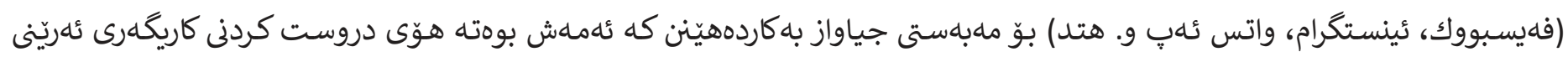

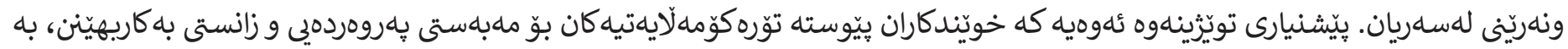

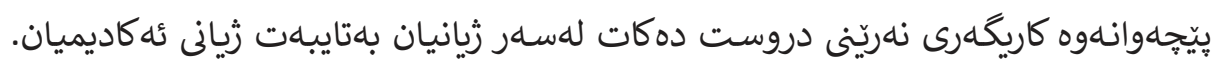

\subsection{Introduction}

\subsection{Background of the Study}

In recent years, technology has tried to meet its role in serving humanity resulting in the substantial medium of interaction within the social world further as in teaching and learning (Boateng, et al, 2016). Social media plays a significant role in students' life as data technology modified people's normal life. Students will connect with others within seconds and share their ideas and provide comments by video conferencing. Social Media influence student's life, with its each positive and negative impact. Students conjointly use social media for learning purposes, for amusement, and innovation (Ali et al, 2016, 369-372). Technology has shown a speedy development by introducing little communication devices. We will use these small communication devices for accessing social media anytime, anyplace, as these gadgets embrace pocket computers, laptops, iPads, and even easy mobile phones (which support the internet).

\subsection{Statement of the Problem}

With the explosive growth within the range and use of social media in everyday communication techniques for people and organizations, there has been a corresponding increase of its incorporation in teaching and academic performance. Visible of this, this study attempts to decide on the impact that social media has on the students' academic performance in education, whether or not positive or negative, and its relationship with academic performance.

\subsection{Purpose of the Study}

This study is supposed to assess the relationship and impact of social media on students' academic performance within the University of Halabja. Also, it tries to concentrate on how these media impact their goals in the future. 


\subsection{Research Questions}

Does social media affect students' academic performance positively or negatively?

\subsection{Significance of the study}

This study tries to give an understanding of how social media is employed by university students and the way it's influencing their learning and academic performances. The result of the study can facilitate to strategize and reconstruct their angle concerning the utilization of social media. This analysis is going to be an inevitable tutorial supply and pave the manner for college students to understand the consequences of social media, and therefore the effects on the undergraduates' academic performances. It will raise the attention of the individuals regarding either positive or negative impacts of social media on the academic performances of students.

\subsection{Limitation of the study}

The results of this study are restricted to the students of the University of Halabja, Halabja Governorate - Kurdistan region - Iraq, who are from eight departments (Physics, Computer Science, Law, English language, Arabic language, History, Social Sciences, and Physical Education). It is simply restricted to seek out the positive and negative impacts of social media on the undergraduates' academic performances and its relationship with academic performance.

\subsection{Review of the Related Literature}

The term "Social Media" is outlined because the application permits users to converse and move with every other; to make, edit and share new types of matter, visual and audio content, and to categorize, label, and suggest existing types of content. Social media so denotes the wide assortment of net-primarily based and mobile services that connect folks along to speak, participate, collaboratively move, discuss and exchange ideas and data on an internet community. It represents an associate degree more and more necessary context in one's tutorial daily life. Students these days use social media anyplace and at any time where net affiliation is on the market to fulfil their instructional demands (Boateng, et al, 2016). Students use social media to speak with their academics as a bunch outside of sophistication and to set up university events and whatnot, it conjointly permits students to induce assistance on university work from academics throughout the evening, weekends, and holidays so that they never fall behind. The high speed and quick approach to the net and therefore the development of sensible phone technology are the most vital drivers behind the adoption and property with social media and conclude that social media enhance their data level (Mim et al, 2018, 299-302).

Student users are plagued by the web. This impact is set by the kind of internet usage. They're plagued by the informative use of web whereas having a forceful impact of recreational use of internet on them. Also, it's advantageous to each student and lecturers if used as a tool of information creation and dissemination 
(Mehmood et al, 2013, 111-123). (Jacobsen et al, 2011, 275-280) said, media had a negative result on grades, regarding the common fraction of the scholars used media whereas doing prep, or in school that had an unhealthy impact on their grades. Students ought to manage and monitor their time spent in the victimization of Social Media (Mushtaq et al, 2018). In short, fashionable technology has several positive aspects. However, at the same time; it should become risky for the users. It's, thus, the study is conducted for the university students. However, they feel and suppose the results of social media on their academic performance and their behaviour amendment. The most important objective of this study is to explore the results of social media participation in the students' academic performance.

\subsection{Methodology}

The purpose of assembling this knowledge was to perform a gaggle analysis of how social media affect college students. During this analysis, an associate anonymous form was administered to gather knowledge that was the quality survey assortment methodology. For this, a semi-standardized form has been distributed among 320 students at the University of Halabja in Jan 2020. Information was collected between Jan twenty-six and Feb twenty-three, 2020 by employing a form. The form was in the paper version. Every interview took roughly fifteen to twenty minutes and the interviews were conducted in Kurdish. The University of Halabja is a new university and it just includes 13 colleges currently. The students were selected through a circular systematic sampling from eight different departments (Physics, Computer Science, Law, English language, Arabic language, History, Social Sciences, and Physical Education). Originally, the analysis style foresaw the participation of ten students from each BA year of the eight departments. On condition that participation was entirely voluntary, just 295 out of the chosen 320 students crammed out the form. Since there are more females than males at the University of Halabja, six of the ten selected participants for every BA year and department were females, the remaining four participants were males. Per the respondents, males $(n=118)$ and females $(n=177)$ were concerned during this survey. The participants were asked to reply to fourteen queries. The main focus of the queries was the range of aspects from that the students use social media. To analyze and examine the relationship between the research variables, the researchers used IBM SPSS Statistic Software, V22 (Armonk, 2013) and the Chi-Square Test of Independence which is used to determine if there is a significant relationship between two nominal (categorical) variables (Pearson. K., 1900, 157-175). The frequency of each category for one nominal variable is compared across the categories of the second nominal variable. The data can be displayed in a contingency table where each row represents a category for one variable and each column represents a category for the other variable. This test is also known as Chi-Square Test of Association. The critical value for the chi-square statistic is determined by the level of significance (typically $\alpha=.05$ ) and the degrees of freedom for the chi-square, and degree of freedom $(d f)=(r-1)(c-1)$ where $r$ is the number of rows and $c$ is the number of columns. This test utilizes a contingency table to analyze the data. A contingency table (also known as a 
cross-tabulation, crosstab, or two-way table) is an arrangement in which data are classified according to two categorical variables. The value of the Chi-Square Test of the Independence:

$\chi^{2}=\sum_{i=1}^{r} \sum_{j=1}^{c} \frac{\left(O_{i j}-E_{i j}\right)^{2}}{E_{i j}}$, where

$\chi^{2}=$ Chi - Square of Independence.

$O_{i j}=$ Obseved value of two nominal variables.

$E_{i j}=$ Expected value of two nominal variables.

\subsection{Research Hypothesis}

$\mathrm{H}_{0}$ : There is no significant relationship between our variables.

$\mathrm{H}_{1}$ : There is a significant relationship between our variables.

\subsection{Discussion of Results}

The results of this research indicate that a total of 295 undergraduate students at the University of Halabja responded to the questionnaire. According to the data the researchers collected from the anonymous questionnaire, $100 \%$ of the students at the University of Halabja used social media. The researchers explained how students have participated in eight different departments from many different colleges. It becomes clear to the researchers that the students of the Department of Physics and Arabic language have the highest participation rate in filling out the form which reaches $13.6 \%$. Subsequently, students from the departments of Physical Education, Computer, History and Law participated in the study with13.2\% and 12.9\% (Table1).

It is also clear from the table1 that students in the English language and social sciences departments participated in a lower rate, ranging from $10.2 \%$ to $10.8 \%$. Based on gender, the student participation rate and the sample of the study, which makes it clear to us that $40.0 \%$ of the participants in the study sample, were of the male sex and $60.0 \%$ of them were female. This goes back to the fact that in many parts of the world the female sex ratio is higher than the male sex ratio.

Table1 Descriptive Statistic for Demographic Questions:

\begin{tabular}{|c|c|c|c|}
\hline \multicolumn{2}{|c|}{ Demographic Questions } & F & Per cent (\%) \\
\hline \multirow{3}{*}{ Department } & Physic & 40 & $13.6 \%$ \\
\cline { 2 - 4 } & Computer & 38 & $12.9 \%$ \\
\cline { 2 - 4 } & law & 38 & $12.9 \%$ \\
\cline { 2 - 4 } & English & 30 & $10.2 \%$ \\
\cline { 2 - 4 } & Social Science & 32 & $10.8 \%$ \\
\cline { 2 - 4 } & History & 38 & $12.9 \%$ \\
\cline { 2 - 4 } & Arabic & 40 & $13.6 \%$ \\
\cline { 2 - 4 } & Physical Education & 39 & $13.2 \%$ \\
\hline \multirow{4}{*}{ Gender } & Male & 118 & $40.0 \%$ \\
\cline { 2 - 4 } & Female & 177 & $60.0 \%$ \\
\hline
\end{tabular}




\begin{tabular}{|c|c|c|c|}
\hline \multirow{4}{*}{ BA year } & 1st year & 79 & $26.8 \%$ \\
\cline { 2 - 4 } & 2nd year & 78 & $26.4 \%$ \\
\cline { 2 - 4 } & 3rd year & 78 & $26.4 \%$ \\
\cline { 2 - 4 } & 4th year & 60 & $20.3 \%$ \\
\hline \multirow{4}{*}{ Age group } & $17-20$ & 70 & $23.7 \%$ \\
\cline { 2 - 4 } & $20-23$ & 168 & $56.9 \%$ \\
\cline { 2 - 4 } & $23-26$ & 49 & $16.6 \%$ \\
\cline { 2 - 4 } & $26-29$ & 4 & $1.4 \%$ \\
\cline { 2 - 4 } & $29+$ & 4 & $1.4 \%$ \\
\hline \multirow{2}{*}{$\begin{array}{c}\text { Do you live in the dormitory or in the } \\
\text { city? }\end{array}$} & Dormitory & 177 & $60.0 \%$ \\
\cline { 2 - 4 } & City & 118 & $40.0 \%$ \\
\hline \multirow{3}{*}{\begin{tabular}{c} 
Economy Status \\
\cline { 2 - 4 }
\end{tabular}} & Very good & 10 & $3.4 \%$ \\
\cline { 2 - 4 } & Good & 135 & $45.8 \%$ \\
\cline { 2 - 4 } & Middle & 142 & $48.1 \%$ \\
\hline \multirow{2}{*}{\begin{tabular}{c}
$*$ \\
\cline { 2 - 3 }
\end{tabular}} & Bad & 8 & $2.7 \%$ \\
\hline
\end{tabular}

Based on table1, another question is specific to the proportion of students participating in the sample of the study according to the stages, which are close to a good degree. The first, second and third stages, which have a good turnout rate, are close to $26 \%$ for each section. This is important for the knowledge of the existence of the study. Those who are less involved are the students of the fourth stage of the section who contributed $20 \%$ this was due to the fact that students in some departments visited the schools while filling out the forms for the purpose of the application.

The results of table1 show that the proportion of $23.7 \%$ of our sample is aged between (17-20) years. This age is more likely to be a first-year student. $56.9 \%$ of the study sample was between the ages of (20-23) years. Of the $16.6 \%$ of the sample, they are between the ages of (23-26) years old, which may include more fourth-year students. However, in this medium, a very small proportion of the participants are over the age of 26 , which makes up about $2.8 \%$ of all participants.

According to the place of residence of the students, $60.0 \%$ of the sample being students from outside the city of Halabja, that is, from a city or district, and from another village to study and reside in the local department. This is an important point for the cultural integration and revitalization of the city of Halabja. $40.0 \%$ of the sample members of the study who live on the border of the city of Halabja, again, this is an indication of the importance of educating the people, families and individuals of Halabja in the field of education, especially university education.

On the other hand, the result is specific to knowing the living standards and income of students in the family. Unfortunately, due to the deteriorating financial situation in the Kurdistan Region in recent years, there is a complete sense of deterioration in the livelihoods of people and families, and the impact on education and university students. The data indicate that only $3.4 \%$ of the sample members of the study have a very good 
financial situation, which is actually a very low rate. On the other hand, the proportion of $45.8 \%$ of the study sample is financially good in the sense that they can provide for their living needs. For the $48.1 \%$ of the sample, the economic situation is moderate, which is, unfortunately, a high proportion of the sample, which is a dangerous place for the future of their students and their families. The fact that close to $2.7 \%$ of the sample is in poor condition is because they are not able to provide their daily needs well.

According to the data we collected in our research, $64.5 \%$ of our students used more than five accounts in the social media, In this ratio, we can realize in one way that students keep up with technological developments, and in another way, we can recognize that needs of life have been so highly increased that we should be greatly aware of the unrealistic life around us. Regarding the use of social media types by students, the use of messengers by students has the highest rate of enrollment, $40.3 \%$ of the students who are more of a messenger user compared to others. Since then, $28.5 \%$ of students have become Facebook users, as only Kurds are more familiar with this type of social network compared to others that are relatively new. The Instagram social media is also the third most valued media used by students at a rate of $12.2 \%$. This is followed by each one (Snap Chat, Viber and YouTube) which is less than $10 \%$ used differently by the students. This topic is a private, individual, and individual topic, but they are generally more economically viable, using messenger for example (Table2). From other findings of the table2, which is specific to the hours spent by university students on the use of social media daily, in general, $44.4 \%$ of our students spent (1-3) hours per day. $27.8 \%$ use (3-5) hours of social media. In return, the rate of $15.9 \%$ of students use more than (5) hours of social media per day. The lowest amount of time spent on social media is the rate of $11.9 \%$ of the study sample.

Table2 Descriptive Statistic for survey questions

\begin{tabular}{|l|c|c|c|}
\hline \multicolumn{2}{|c|}{ Questions } & $F$ & Per cent (\%) \\
\hline \multirow{3}{*}{ How many Social Media do you use? } & $1-4$ & 105 & $35.6 \%$ \\
\cline { 2 - 4 } & $5-7$ & 190 & $64.4 \%$ \\
\hline \multirow{4}{*}{$\begin{array}{l}\text { Which Social Media do you use more than } \\
\text { others? }\end{array}$} & Facebook & 84 & $28.5 \%$ \\
\cline { 2 - 4 } & messenger & 119 & $40.3 \%$ \\
\cline { 2 - 4 } & Instagram & 36 & $12.2 \%$ \\
\cline { 2 - 4 } & Viber & 6 & $2.0 \%$ \\
\cline { 2 - 4 } & Snap chat & 29 & $9.8 \%$ \\
\cline { 2 - 4 } & YouTube & 21 & $7.1 \%$ \\
\cline { 2 - 4 } & & & \\
\hline
\end{tabular}




\begin{tabular}{|c|c|c|c|}
\hline \multirow{4}{*}{$\begin{array}{c}\text { How many hours do you use Social } \\
\text { Media in the daytime? }\end{array}$} & $0-1$ & 35 & $11.9 \%$ \\
\hline & $1-3$ & 131 & $44.4 \%$ \\
\hline & $3-5$ & 82 & $27.8 \%$ \\
\hline & $5+$ & 47 & $15.9 \%$ \\
\hline \multirow{2}{*}{$\begin{array}{l}\text { Do you use Social Media for university } \\
\text { work? }\end{array}$} & yes & 240 & $81.4 \%$ \\
\hline & no & 55 & $18.6 \%$ \\
\hline \multirow{2}{*}{ Do you use Social Media for chatting? } & yes & 274 & $92.9 \%$ \\
\hline & no & 21 & $7.1 \%$ \\
\hline \multirow{2}{*}{$\begin{array}{l}\text { Do you use Social Media for } \\
\text { entertainment? }\end{array}$} & yes & 221 & $74.9 \%$ \\
\hline & no & 74 & $25.1 \%$ \\
\hline \multirow{2}{*}{ Has Social Media positively affected you? } & yes & 223 & $75.6 \%$ \\
\hline & no & 72 & $24.4 \%$ \\
\hline \multirow{2}{*}{$\begin{array}{c}\text { Has Social Media negatively affected } \\
\text { you? }\end{array}$} & yes & 139 & $47.1 \%$ \\
\hline & no & 156 & $52.9 \%$ \\
\hline \multirow{2}{*}{$\begin{array}{l}\text { Do you consider yourself addicted to } \\
\text { Social Media? }\end{array}$} & yes & 153 & $51.9 \%$ \\
\hline & no & 142 & $48.1 \%$ \\
\hline \multirow{2}{*}{$\begin{array}{l}\text { Social Media's negative effect on } \\
\text { students' scientific level }\end{array}$} & yes & 181 & $61.0 \%$ \\
\hline & no & 114 & $39.0 \%$ \\
\hline \multirow{2}{*}{$\begin{array}{l}\text { Social Media has a negative effect on } \\
\text { students' social life. }\end{array}$} & yes & 211 & $72.0 \%$ \\
\hline & no & 84 & $28.0 \%$ \\
\hline \multirow{2}{*}{$\begin{array}{l}\text { Social Media has a negative effect on } \\
\text { students' daily life. }\end{array}$} & yes & 198 & $67.0 \%$ \\
\hline & no & 97 & $33.0 \%$ \\
\hline \multirow{2}{*}{$\begin{array}{l}\text { Family education affects how well } \\
\text { students use Social Media. }\end{array}$} & yes & 244 & $83.0 \%$ \\
\hline & no & 51 & $17.0 \%$ \\
\hline
\end{tabular}

Psychological and sociological research reveal the fact that the more a person is a user of social media, the more he or she suffers from a psychological, social, and social problems. In general, we can say that a large part of the students and the sample of the study devoted more time to their use of the social media, apart from some problems (educational, emotional, psychological, social, family, friendship) that students face as a result of this social networking system, without a plan and without time.

Also, from table2, it is clear to us that $81.4 \%$ of our sample of the study use the subject of science and the promotion of university affairs, which is a positive result. This means that the use of technology by this number is very much for university work. On the other hand, a small proportion of $18.6 \%$ do not use it for university work, and they use it more for personal and time-consuming purposes.

In the answer of the question whether you use social media to chat, talk, and talk to the opposite sex, $92.9 \%$ of the sample members of the research responded to the question with "yes". In contrast, the percentage of 7.1\% answered "no". In fact, it would be normal if a large number of participants used the social media for chatting as the nature of social media is that it is used more for that purpose. About using social media to spend time and fill free time (entertainment), a rate of $74.9 \%$ of the sample of the study use social media for that subject, and in return, $25.1 \%$ use them for other subjects (table2).

Other findings of table2 concerning the positive and negative impact of the use of technology on the sample of the study show that the use of technology and the use of social media have had a positive effect on $75.6 \%$ of the sample. This is a fair amount. We can say that it was more beneficial compared to the rate of 
$24.4 \%$ of the sample of the study that they thought had a negative effect on them. In fact, the proportion of the sample that had a negative effect on them was similarly high, and one in four of the sample of the study think that appropriate solutions need to be found to their problems. And for the question that addressed to the negative effects of social media on the sample of the study, which contains a total of $47.1 \%$ of the sample believed that the use of social media has left a lasting impression on them. This means that from time to time they suffer from mental or social damage...etc. when used. This reflects a high level of anxiety and a weakened level of enlightenment and awareness of our role models. In the face of this rate, $52.9 \%$ of the students believe that the social media has left a negative impact on them. Also, our students explained that they are addicted to social media with the percentage of $51.9 \%$.

Moreover, it is clear from table2 that the proportions of $61.0 \%$ of the sample members believe that social media affected their scientific level negatively. This is a very high point and highlights the fact that the level of knowledge of students in the future is in danger. In contrast to this rate, 39.0\% of the members of the sample indicated that social media did not leave a negative impact on them. But the rate is lower compared to the others. From the point of view of sociology and psychology, all university students need to take a stand on this point and make it a point of self-reflection. The question of the influence of social media on the social life and social relations of students, $72.0 \%$ of students believe that social media have left a negative impact on social life and social relations. In contrast, only $28.0 \%$ of the study's sample believes that their level of communication and social life is stable. Social relationships and social life are very important for young people and the youth stage and part of the problems of their lives will be solved in that way. On the other hand, concerning social media's negative impact on students' daily life, sixty-seven per cent of the study's respondents answered with "yes", meaning that social media has a negative impact on their daily lives, and they feel it. In fact, the rate is so high that the rate of $33.0 \%$ of the study sample is believed to have not affected their daily lives, which is a small amount compared to the previous rate. And $83.0 \%$ of the study's sample members thought that the family had an influence on them on how they used social media. A high rate of positive effect, compared with $17.0 \%$ of the study's sample, suggest that the family did not affect them. This is even more evident in families where the climate of complete democracy has spread over their families and members, and every individual has his or her own freedom and independence. 
Test the Hypotheses

Table3 Chi-Square Test between demographic questions and Social Media has a negative effect on student's scientific level (Y1).

\begin{tabular}{|c|c|c|c|c|c|c|}
\hline \multirow{2}{*}{\multicolumn{2}{|c|}{ Demographic questions }} & \multicolumn{2}{|c|}{ Y1 } & \multirow{2}{*}{ Total } & \multirow{2}{*}{$\begin{array}{l}\text { Chi- } \\
\text { Square } \\
\text { Value }\end{array}$} & \multirow{2}{*}{ P-Value } \\
\hline & & \multirow{2}{*}{$\begin{array}{c}\text { Yes } \\
38\end{array}$} & \multirow{2}{*}{$\begin{array}{c}\text { No } \\
41 \\
\end{array}$} & & & \\
\hline \multirow{4}{*}{$\begin{array}{c}\text { In which } \\
\text { year of your } \\
\text { BA are } \\
\text { you? }\end{array}$} & 1st year & & & 79 & \multirow{5}{*}{14.085} & \multirow{5}{*}{0.003} \\
\hline & 2nd year & 59 & 19 & 78 & & \\
\hline & 3 rd year & 44 & 34 & 78 & & \\
\hline & 4 th year & 40 & 20 & 60 & & \\
\hline \multicolumn{2}{|c|}{ Total } & 181 & 114 & 295 & & \\
\hline \multirow{2}{*}{$\begin{array}{l}\text { Do you live } \\
\text { in a } \\
\text { dormitory } \\
\text { or in the } \\
\text { city? }\end{array}$} & dormitory & 119 & 58 & 177 & \multirow{3}{*}{6.443} & \multirow{3}{*}{0.008} \\
\hline & In the City & 62 & 56 & 118 & & \\
\hline \multicolumn{2}{|c|}{ Total } & 181 & 114 & 295 & & \\
\hline
\end{tabular}

The results of our hypotheses show that, as shown in the table3, for the first demographic question, the statistical analysis revealed that because the $p$-value 0.003 is less than our chosen significance level $\alpha=0.05$, we can see that there is very strong evidence against the null hypothesis ( $H_{-} 0$ ) with $99 \%$ confidence, which is to be rejected. Therefore, we can observe that there is a very strong significant and statistically relevant relationship between students' BA year and social media's negative effect on their scientific level. Clearly, we see that for the second BA year $26.4 \%$, using social media affected the students more negatively, followed by the third year, fourth year and the first year.

And also for the second demographic question, with $99 \%$ confidence we reject the null hypothesis, because the $p$-value 0.008 is less than our chosen significance level $\alpha=0.05$. It means there is very strong evidence against the null hypothesis $\left(\mathrm{H}_{-} \mathrm{O}\right)$, and we can observe that there is a very strong significant and statistically relevant relationship between living students in the dormitory or their own city and social media's negative effect on students' scientific level. Here we noticed that for the students that are living in the dormitory $60.0 \%$, using social media affected them negatively in their scientific level more than those students who live in their own city, because those students who live in the dormitory, may use social media to fulfil their psychological and social lives, like communicating with their families and friends. So, for those students that live in dormitory we see a more negative effect. And for all other demographic questions (table1), the p-value that we found is greater than our chosen significance level $\alpha=0.05$. So, the rejection of the null hypothesis fails. 
Table4 Chi-Square Test between demographic questions and Social Media has a negative effect on the students' social life (Y2).

\begin{tabular}{|c|c|c|c|c|c|c|}
\hline \multirow{2}{*}{\multicolumn{2}{|c|}{ Demographic questions }} & \multicolumn{2}{|c|}{ Y2 } & \multirow{2}{*}{ Total } & \multirow{2}{*}{$\begin{array}{l}\text { Chi- } \\
\text { Square } \\
\text { Value }\end{array}$} & \multirow{2}{*}{ P-Value } \\
\hline & & Yes & $\mathrm{No}$ & & & \\
\hline \multirow{4}{*}{$\begin{array}{c}\text { In which } \\
\text { year of your } \\
\text { BA are } \\
\text { you? }\end{array}$} & 1st year & 47 & 32 & 79 & \multirow{5}{*}{9.605} & \multirow{5}{*}{0.022} \\
\hline & 2nd year & 59 & 19 & 78 & & \\
\hline & 3rd year & 63 & 15 & 78 & & \\
\hline & 4th year & 42 & 18 & 60 & & \\
\hline \multicolumn{2}{|c|}{ Total } & 211 & 84 & 295 & & \\
\hline
\end{tabular}

Based on table4, when our p-value .022 is less than our chosen significance level $\alpha=.05$. Also, it can be observed that there is a very strong significant and statistically relevant relationship between students' BA year and social media's negative effect on students' social life with confidence $95 \%$. Here our data show that for the third BA year $26.4 \%$, using social media affected students' social life more negatively than the three other stages. And for all the other demographic questions (table1), the p-value that we found is greater than our chosen significance level $\alpha=.05$. So, the rejection of the null hypothesis fails.

Based on the table5, since our $p$-value .04 is less than our chosen significance level $\alpha=.05$, we can see that there is very strong evidence against the null hypothesis $\left(\mathrm{H}_{-} \mathrm{O}\right)$ with $95 \%$ confidence, which is to be rejected. Therefore, we can observe that there is a very strong significant and statistically relevant relationship between students' BA year and social media's negative effect on students' daily life. Also, we can see that the second and third BA year students' daily life is more affected by social media negatively than the other two stages.

Table5 Chi-Square Test between demographic questions and Social Media has a negative effect on students' daily life (Y3).

\begin{tabular}{|c|c|c|c|c|c|c|}
\hline \multirow{2}{*}{\multicolumn{2}{|c|}{ Demographic questions }} & \multicolumn{2}{|c|}{$\mathrm{Y} 3$} & \multirow{2}{*}{ Total } & \multirow{2}{*}{$\begin{array}{l}\text { Chi- } \\
\text { Square } \\
\text { Value }\end{array}$} & \multirow{2}{*}{ P-Value } \\
\hline & & Yes & No & & & \\
\hline \multirow{4}{*}{$\begin{array}{l}\text { In which year of } \\
\text { your BA are you? }\end{array}$} & 1 st year & 43 & 36 & 79 & \multirow{5}{*}{8.31} & \multirow{5}{*}{0.04} \\
\hline & 2nd year & 57 & 21 & 78 & & \\
\hline & 3rd year & 57 & 21 & 78 & & \\
\hline & 4th year & 41 & 19 & 60 & & \\
\hline \multicolumn{2}{|c|}{ Total } & 198 & 97 & 295 & & \\
\hline
\end{tabular}

From the table3, table4 and table5, we can see that using social media affected students' scientific level, social life and daily life negatively according to the BA year. While for all other demographic questions (table1), the $p$-value that we found is greater than our chosen significance level $\alpha=.05$. So, the rejection of the null hypothesis fails.

On the other hand, family members should be on the guard to ensure that the use of social media among students at home does not encroach into the time for their homework and other activities of benefit which 
are supposed to be done at home. For this, table6 shows the relationships between demographic questions and family education affects how well students use social media.

Table6 Chi-Square Test between demographic questions and family education affects how well students use social media (Y4).

\begin{tabular}{|c|c|c|c|c|c|c|}
\hline \multirow{2}{*}{\multicolumn{2}{|c|}{ Demographic questions }} & \multicolumn{2}{|c|}{$\mathrm{Y} 4$} & \multirow{2}{*}{ Total } & \multirow{2}{*}{$\begin{array}{l}\text { Chi- } \\
\text { Square } \\
\text { Value }\end{array}$} & \multirow{2}{*}{ P-Value } \\
\hline & & \multirow{2}{*}{$\begin{array}{c}\text { Yes } \\
37\end{array}$} & \multirow{2}{*}{$\begin{array}{c}\text { No } \\
3\end{array}$} & & & \\
\hline \multirow{8}{*}{$\begin{array}{l}\text { In which department } \\
\text { do you study? }\end{array}$} & Physics & & & 40 & \multirow{9}{*}{14.951} & \multirow{9}{*}{0.037} \\
\hline & Computer & 32 & 6 & 38 & & \\
\hline & Law & 30 & 8 & 38 & & \\
\hline & English & 27 & 3 & 30 & & \\
\hline & Social sciences & 29 & 3 & 32 & & \\
\hline & History & 26 & 12 & 38 & & \\
\hline & Arabic & 35 & 5 & 40 & & \\
\hline & Physical Education & 28 & 11 & 39 & & \\
\hline \multicolumn{2}{|c|}{ Total } & 244 & 51 & 295 & & \\
\hline
\end{tabular}

By looking at our result of $p$-value .037 that is less than our chosen significance level $\alpha=.05$, it can be observed that there is a very strong significant and statistically relevant relationship between students' department of study and family education affects how well students use social media with confidence $95 \%$. We can say that the family education of the physics department students is more affected by how well their students using social media than the other study department students. And for all the other demographic questions (table1), the $p$-value that we found is greater than our chosen significance level $\alpha=.05$. So, the rejection of the null hypothesis fails.

Students can do university works with the help of social media. It is clear that if used wisely for educational and constructive purposes, social media can have a positive influence on students' academic performance. Despite the various positive effects that social media can have, if not used properly and vigilantly it can also affect students' academic performance negatively. Many students use social media for chatting and just whiling away their time. This wastes their study time and thus they are not able to complete their homework, assignments or projects on time. This affects their studies negatively. Table7 shows the relationships between gender and using social media for university work, social media's effect on the students in a positive way, and social media's effect on the students in a negative way separately.

Table7 Chi-Square Test between gender and using Social Media for university work, Social Media's effect on the students in a positive way, and Social Media's effect on the students in a negative way separately. 


\begin{tabular}{|c|c|c|c|c|c|c|}
\hline \multicolumn{2}{|l|}{ Questions } & \multicolumn{2}{|c|}{$\begin{array}{c}\text { What is your } \\
\text { gender? }\end{array}$} & \multirow[t]{2}{*}{ Total } & \multirow{2}{*}{$\begin{array}{l}\text { Chi- } \\
\text { Square } \\
\text { Value }\end{array}$} & \multirow[t]{2}{*}{ P-Value } \\
\hline & & Male & Female & & & \\
\hline \multirow{2}{*}{$\begin{array}{l}\text { Do you use Social Media } \\
\text { for university work? }\end{array}$} & yes & 86 & 154 & 240 & \multirow{3}{*}{9.312} & \multirow{3}{*}{0.002} \\
\hline & no & 32 & 23 & 55 & & \\
\hline \multicolumn{2}{|l|}{ Total } & 118 & 177 & 295 & & \\
\hline \multirow{2}{*}{$\begin{array}{c}\text { Has Social Media affected } \\
\text { you positively? }\end{array}$} & yes & 90 & 133 & 223 & \multirow{3}{*}{0.048} & \multirow{3}{*}{0.46} \\
\hline & no & 28 & 44 & 72 & & \\
\hline \multicolumn{2}{|l|}{ Total } & 118 & 177 & 295 & & \\
\hline \multirow{2}{*}{$\begin{array}{c}\text { Has Social Media affected } \\
\text { you negatively? }\end{array}$} & yes & 64 & 75 & 139 & \multirow{3}{*}{4.05} & \multirow{3}{*}{0.03} \\
\hline & no & 54 & 102 & 156 & & \\
\hline \multicolumn{2}{|l|}{ Total } & 118 & 177 & 295 & & \\
\hline
\end{tabular}

By looking at the table7, with a p-value of about .002, which is less than our chosen significance level $\alpha=.05$, we accept to reject the null hypothesis and there is a very strong significant and statistically relevant relationship between gender and using social media for university work with $99 \%$ confidence.

On the other hand, there is a statistically significant association relationship between gender and social media's negative effect on students. The correlation has a strong confidence coefficient of $95 \%$. While for the positive effect with a p-value about .46, which is greater than our significant level .05 , the rejection of the null hypothesis fails. There is insufficient evidence to support the claim that there is a correlation between gender and social media's positive effect on students.

\subsection{Conclusion}

The following conclusions are drawn and created to support related side and students during academic years through statistics:

1. The use of messenger by students has the highest rate of enrollment; Facebook plays the second role, while Instagram is also the third most valued media used by students, each of Snap Chat, Viper and YouTube take fourth, fifth, sixth role among different types of social media respectively.

2. It is clear the great proportion of the sample members believe that social media affected their scientific level negatively; in contrast the small proportion of the sample members indicated that social media did not leave a negative impact on them.

3. It indicated that a large number of students believe that social media have left a negative impact on social life and social relations. In contrast, only the small sample believes that their level of communication and social life is stable. On the other hand, a part of our student believes that social media has a negative impact on their daily lives.

4. In general, we can say that a large part of the students and the sample of the study devoted more time to their use of social media, apart from some problems (educational, emotional, psychological, social, family, friendship) that students face as a result of this social networking system, without a plan and without time. 
5. It can observe that there is a very strong significant and statistically relevant relationship between living students in the dormitory or their own city and social media's negative effect on students' scientific level, those students who live in the dormitory may use social media to fulfill their psychological and social lives, like communicating with their families and friends, that is why for those students we see a more negative effect.

6. There is a statistically significant association relationship between gender and social media's negative effect on students; on other speech male students are more likely used to use social media in a negative way than female students.

7. Our results shows that family education has important role on how well students use social media, and family must take good care of students and motivate them to use social media in a good way, because if they not know how to use it, it affected them in a negative way.

\section{References}

1-Ali. A., Iqbal. A., \& Iqbal. K. (2017). EFFECTS OF SOCIAL MEDIA ON YOUTH: A CASE STUDY IN UNIVERSITY OF SARGODHA. International Journal of Advanced Research (IGAR), 4(11), 369-372.

2- Armonk. NY: IBM Corp. Released in 2013. IBM SPSS Statistics for Windows, Version 22.0.

3- Boateng. R. O., \& Amankwaa. A. (2016). The Impact of Social Media on Student Academic Life in Higher Education. journal of Global Journals Inc. (USA) ,16, ISSN: 2249-460x \& Print ISSN: 0975-587X.

4- Jacobsen. W. C., \& Forste. R. (2011). The Wired Generation: Academic and Social Outcomes of Electronic Media Use Among University Students. CYBERPSYCHOLOGY, BEHAVIOR, AND SOCIAL NETWORKING, 14(5), 275-280.

5- Mehmood. S., \& Taswir. T., (2013). The Effects of Social Networking Sites on the Academic Performance of Students in College of Applied Sciences, Nizwa, Oman. International Journal of Arts and Commerce, 2(1), 111123.

6- Mim. F. N., Islam. M. A., \& Paul. G. K. (2018). Impact of the use of Social Media on students' academic performance and behaviour change. International Journal of Statistics and Applied Mathematics, 3(1), $299-302$. 7- Mushtaq. A. J., \& Benraghda. A. (2018). The Effects of Social Media on the Undergraduate Students' Academic Performances. Library Philosophy and Practice (e-journal). 1779, https://digitalcommons.unl.edu/libphilprac/1779.

8- Pearson. K. (1900). On the criterion that a given system of deviations from the probable in the case of a correlated system of variables is such that it can be reasonably supposed to have arisen from random sampling. Philosophical Magazine. Series 5. 50(302): 157-175. 